\title{
Optymalny dobór gazomierzy miechowych przez operatora systemu gazowniczego
}

\begin{abstract}
W artykule omówiono wybrane charakterystyki metrologiczne gazomierzy miechowych, które w istotny sposób wpływają na ilość nierozliczonego gazu. Zaprezentowano też aplikację, która na podstawie wprowadzonych charakterystyk metrologicznych danego gazomierza pozwala oszacować skalę wyżej wymienionego zjawiska. Informacją zwrotną z aplikacji jest analiza ekonomiczna uwzględniająca koszty zakupu gazomierza oraz wielkość zysków lub strat związanych z jego funkcjonowaniem w całym okresie eksploatacji. Porównując w ten sposób kilka typów gazomierzy, kupujący (operator systemu gazowniczego) może dokonać takiego wyboru, który w bliższej lub dalszej przyszłości przełoży się na wymierne korzyści finansowe.
\end{abstract}

Słowa kluczowe: gazomierz miechowy, nierozliczone ilości gazu, parametry gazomierzy, charakterystyka metrologiczna, początkowe błędy wskazań, trwałość gazomierzy, stabilność gazomierzy.

\section{Optimal selection of diaphragm gas meters by the operator of a gas system}

In the article selected metrological characteristics of diaphragm gas meters, which significantly affect the amount of unaccounted gas were discussed. An application which allows to estimate the scale of this phenomenon based on the input of metrological characteristics of the meter, has been presented in this article as well. The feedback from the application is the price balance that takes into account the cost of purchasing the gas meter and the amount of profits or losses, related to its functioning during the whole period of operation. Comparing a few groups of meters in such a way, the buyer can make a more qualified choice, which sooner or will translate into tangible financial benefits.

Key words: diaphragm gas meter, unsettled amounts of gas, the parameters of gas meters, metrological characteristics, initial errors of indication, durability of diaphragm gas meter, gas meter stability.

\section{Wprowadzenie}

W strukturze zużycia energii pierwotnej w Polsce gaz ziemny zajmuje trzecie miejsce, za węglem i ropą naftową. W ostatnich latach jego zużycie w naszym kraju kształtowało się na poziomie około 14,5 $\mathrm{mld}^{3}$ [6]. Gaz ziemny w Polsce ma zastosowanie przede wszystkim w przemyśle, wykorzystującym 60\% (w tym zakłady nawozów azotowych: 19\% oraz elektrownie i elektrociepłownie: 9\%) całości konsumpcji. Odbiorcy sektora komunalno-bytowego stanowią 97\% odbiorców końcowych gazu (około 7,3 mln), a zużywają około $27 \%$ całkowitej ilości sprzedawanego gazu w Polsce [5].

Według polskich przepisów koszt zakupu i wymiany gazomierzy pokrywa operator systemu gazowniczego. W przypadku konieczności zakupu większej liczby urządzeń pomiarowych koszty te często sięgają milionów złotych. Dodat- kowo mogą się one jeszcze zwiększyć, jeśli weźmie się pod uwagę straty związane z nierozliczoną ilością gazu. Jak wykazały przeprowadzone $\mathrm{w}$ ramach niniejszej pracy analizy, koszty te mogą osiągnąc znaczny poziom, często wielokrotnie przewyższając sam koszt zakupu gazomierzy. $Z$ tego powodu bardzo ważne z punktu widzenia kupującego jest wzięcie pod uwagę nie tylko ceny liczników gazu i ich funkcjonalności, ale też ich parametrów metrologicznych. Porównanie parametrów metrologicznych nie jest jednak łatwe. Wymaga to posiadania sporej wiedzy i doświadczenia na temat samego gazomierza, jego działania i właściwości, jak i znajomości specyfiki warunków, w jakich to urządzenie będzie pracować, i czynników środowiskowych, jakim może zostać poddane w całym okresie eksploatacji. Z pomocą 
kupującemu może w tym zakresie przyjść aplikacja opracowana w Zakładzie Metrologii Przepływów INiG - PIB, po- zwalająca na porównanie ze sobą parametrów gazomierzy w celu dokonania optymalnego wyboru.

\section{Gazomierze miechowe}

Gazomierz miechowy jest to gazomierz o konstrukcji komorowej, o ruchomych przegrodach wykonanych częściowo z wiotkiego materiału, które razem z obudową tworzą miechy. Obecnie miechy wykonuje się z materiałów syntetycznych. Mechanizm pomiarowy pracuje na zasadzie swobodnej membrany. Ruch mechanizmu wywołany jest różnicą ciśnień między króćcem wlotowym a wylotowym gazomierza. Komory pomiarowe w trakcie pracy sa na przemian wypełniane gazem i opróżniane. System przekładni przenosi ruch miechów na wałek korbowy. Ten z kolei poprzez zasuwy steruje przepływem gazu. Ruch obrotowy przekładni przenoszony jest poprzez sprzęgło magnetyczne na liczydło. Obudowy gazomierzy wytwarza się na ogół z blachy stalowej łączonej na zakładkę i są one wzmacniane opaską. Wielkość gazomierza dobiera się w zależności od przewidywanego strumienia maksymalnego i minimalnego [15]. Typoszereg stosowanych gazomierzy miechowych podano w tablicy 1 [1]. Wielkości gazomierzy w zależności od ich przeznaczenia przedstawiono $\mathrm{w}$ tablicy 2 [8].

Na podstawie badań przytoczonych w [3] zużycie gazu ziemnego wysokometanowego w Polsce na jedną osobę wynosi $300 \mathrm{~m}^{3} /$ rok $\left(50 \mathrm{~m}^{3} /\right.$ rok na przyrządzanie potraw oraz $250 \mathrm{~m}^{3} /$ rok na podgrzewanie wody) - taryfy W1 i W2. W przypadku gdy gaz używany jest dodatkowo do ogrzewania, roczne zużycie w gospodarstwie waha się od $1500 \mathrm{~m}^{3}$ do $4000 \mathrm{~m}^{3}$ i zależy od powierzchni użytkowej mieszkania, liczby osób oraz pogody w okresie zimowym - taryfy W2 i W3.

Poprawny dobór gazomierza miechowego dostosowanego do warunków, w jakich ma pracować, wymaga sporej wiedzy i doświadczenia. Następstwami nie- właściwego doboru wielkości gazomierza dla operatora systemu gazowniczego są [8]:

- wyższy całkowity koszt eksploatacji - z uwagi na znacznie wyższe koszty pośrednie,

- nierozliczona ilość gazu, rosnąca z upływem czasu,

- częstsza jego wymiana - z uwagi na krótszy okres życia,

- wyższy koszt legalizacji ponownej - z uwagi na:

- większy odsetek odrzutów przy legalizacji ponownej (szczególnie dla próby losowej),

- większą liczbę gazomierzy wymagających adjustacji przy ponownej legalizacji,

- koszty utrzymania/naprawy.

Całkowity koszt podczas pełnego cyklu eksploatacji gazomierza to koszty [8]:

- bezpośrednie, tj. koszt zakupu gazomierza (cena),

- pośrednie, tj. koszt obsługi (utrzymanie, odczyt, kalibracja),

- nierozliczonego gazu podczas okresu eksploatacji (dokładność, trwałość, manipulacje),

- wymiany licznika z uwzględnieniem jego złomowania.

Tablica 1. Typoszereg gazomierzy miechowych

\begin{tabular}{|l|c|c|c|r|c|c|c|c|}
\hline \multicolumn{1}{|c|}{ Wielkość gazomierza } & G1,6 & G2,5 & G4 & G6 & G10 & G16 & G25 & G40 \\
\hline Próg rozruchu $\left[\mathrm{dm}^{3} / \mathrm{h}\right]$ & 3 & 5 & 5 & 8 & 13 & 13 & 20 & 32 \\
\hline Strumień minimalny $\left[\mathrm{m}^{3} / \mathrm{h}\right]$ & 0,016 & 0,025 & 0,040 & 0,060 & 0,10 & 0,16 & 0,25 & 0,40 \\
\hline Strumień maksymalny $\left[\mathrm{m}^{3} / \mathrm{h}\right]$ & 2,500 & 4,000 & 6,000 & 10,000 & 16,00 & 25,00 & 40,00 & 65,00 \\
\hline
\end{tabular}

Tablica 2. Wielkości gazomierzy miechowych w zależności od ich przeznaczenia

\begin{tabular}{|c|c|c|}
\hline Zastosowanie & Wielkość zużycia & Wielkość gazomierza \\
\hline Gotowanie & Niskie zużycie & $\mathrm{G} 1,6$ \\
\hline Gotowanie, podgrzewanie wody & Średnie zużycie & $\mathrm{G} 2,5$ \\
\hline \multirow{2}{*}{$\begin{array}{c}\text { Gotowanie, podgrzewanie wody, } \\
\text { ogrzewanie }\end{array}$} & $\begin{array}{c}\text { Wysokie zużycie } \\
\text { (odbiorcy komercyjni) }\end{array}$ & $\mathrm{G} 4$ \\
\cline { 2 - 3 } & $\begin{array}{c}\text { Zmienne zużycie } \\
\text { (różni odbiorcy) }\end{array}$ & Multi \\
\hline
\end{tabular}

\section{Parametry gazomierzy}

Według [2] dobór gazomierza miechowego należy przeprowadzić na podstawie:

- minimalnego, maksymalnego oraz najbardziej prawdopodobnego profilu poboru gazu,
- objętości cyklicznej,

- dopuszczalnej temperatury gazu podczas jego transportu i magazynowania,

- dopuszczalnej temperatury otoczenia, 
- okresu ważności legalizacji lub jego przewidywanego okresu pracy,

- prognozowanego zużycia gazu w okresie ważności legalizacji lub w przewidywanym okresie pracy,

- stabilności błędu wskazań (trwałość).

Wybór odpowiedniego gazomierza wymaga od kupującego sporej wiedzy i doświadczenia. Z uwagi na dużą liczbę producentów gazomierzy, zarówno w kraju, jak i za granicą, oraz różnorodność konstrukcji tych urządzeń, zazwyczaj zdarza się, że wymagane kryteria spełnia więcej niż jeden typ gazomierza. Odpowiedź na pytanie, na który z nich wtedy się zdecydować, można uzyskać po przeprowadzeniu szczegółowej analizy, polegającej na porównaniu ich parametrów metrologicznych. Celem tej analizy jest wytypowa- nie takiego gazomierza, który w ciągu całego okresu przewidywanej eksploatacji przyniesie najmniej strat, a więc takiego, który z uwagi na właściwości metrologiczne wykaże się najmniejszym wpływem czynników zewnętrznych (temperatura, czas itp.) na swoje wskazania. Analiza powinna również uwzględniać ograniczenia wynikające z obowiązujących przepisów. Efektem przeprowadzonej analizy jest opracowanie specjalnej aplikacji opisanej w niniejszym artykule. Na podstawie norm [18] i [19] oraz dostępnej literatury zebrano wszystkie istotne parametry i cechy charakterystyczne dla gazomierzy miechowych. Następnie, opierając się na wiedzy i doświadczeniu pracowników Zakładu Metrologii Przepływów INiG - PIB, wytypowano te parametry, które mają największy wpływ na wskazania gazomierza.

\section{Początkowe błędy wskazań}

Nowy zalegalizowany - lub po weryfikacji pierwotnej - gazomierz, który trafia do odbiorcy gazu, powinien gwarantować taki poziom błędów pomiaru, aby mieścił się on w maksymalnych dopuszczalnych granicach. Jednakże na ogół gazomierze są przez producentów justowane w taki sposób, aby krzywa błędów wskazań (z wyjątkiem zakresu od $0,7 Q_{\max }$ do $Q_{\max }$ i częściowo w $Q_{\min }$ ) znajdowała się w obszarze błędów dodatnich. Zakres zmienności poboru paliwa gazowego w gospodarstwach domowych jest bardzo zróżnicowany. Zależy on przede wszystkim od rodzaju, mocy i liczby odbiorników gazowych, a także od warunków klimatycznych, właściwości termoizolacyjnych budynków i innych. Wartość średnia poboru gazu w odniesieniu do odbiorców domowych mieści się w zakresie strumieni od $0,1 Q_{\max }$ do $Q_{\max }$. Stąd też, uwzględniając, iż w tym zakresie strumieni krzywa błędów wskazań znajduje się w obszarze błędów dodatnich, można stwierdzić, że przynajmniej w początkowym okresie eksploatacji gazomierza, w temperaturach dodatnich, pomiar objętości gazu będzie obarczony dodatnim błędem systematycznym [11].

\section{Błędy wskazań w deklarowanym zakresie temperatur}

Zawarte w pracy [11] wyniki badań pozwoliły stwierdzić, że temperatura otoczenia w sposób istotny wpływa na błędy wskazań gazomierzy miechowych. Poddanie gazomierza działaniu temperatury otoczenia powoduje, że nie tylko zewnętrzne części pozostają pod wpływem temperatury, ale także elementy wewnętrzne, w tym układ pomiarowy.

Charakter i wielkość zmian błędów wskazań są uzależnione przede wszystkim od temperatury otoczenia oraz typu gazomierza. Efekt końcowy w postaci przesunięcia krzywej błędów wskazań poszczególnych gazomierzy jest spowodowany zmianą objętości cyklicznej gazomierza, która to zmiana stanowi wypadkową kilku czynników, takich jak:

- zmiana oporów mechanicznych układu rozrządu gazomierza,

- zmiana naprężeń w membranie gazomierza,
- kurczenie się membran gazomierza w ujemnych temperaturach.

Równie istotnym czynnikiem jest szczelność wewnętrzna gazomierza. Ujemna temperatura otoczenia może oddziaływać na membranę urządzenia i prowadzić do powstawania nieszczelności na jej powierzchni. Skutkiem tych nieszczelności będzie zaniżanie wskazań, co jest obserwowane szczególnie w zakresie małych strumieni, bliskich $Q_{\text {min }}$ i $3 Q_{\text {min }}$. Temperatura ujemna może także prowadzić do kurczenia się uszczelek wykonanych z materiałów gumowych, stosowanych do uszczelnień osi pionowych układu pomiarowego, czego następstwem może być także zaniżanie wskazań. Istotną rolę odgrywa też uszczelnienie pomiędzy komorami pomiarowymi a układem rozdzielczym rozrządu gazomierza [11].

\section{Trwałość gazomierza}

Trwałość gazomierzy, określana również jako stabilność metrologiczna długoterminowa, jest zdolnością do od- mierzania objętości gazu ze zmieniającym się w akceptowalnych granicach błędem wskazań w czasie użytkowania 
urządzenia, w okresie ważności legalizacji. Jest jednym $\mathrm{z}$ istotniejszych parametrów gazomierza $\mathrm{z}$ punktu widzenia możliwości jego wieloletniej eksploatacji i rzetelności rozliczeń.

Wszystkie materiały użyte do produkcji urządzenia powinny być odporne na korozję oraz niepodatne chemicznie i termicznie na starzenie w czasie całego okresu użytkowania. Zakłada się, że gazomierz powinien pracować bezobsługowo, tzn. że w czasie jego technicznego życia nie powinny być wykonywane żadne naprawy. Od wielu lat gazomierze są często instalowane na zewnątrz budynków, w szafce w tzw. punkcie gazowym. Najbardziej wrażliwe na zmiany temperatury są elementy elastyczne, np. membrany, które znajdują się w ciągłym ruchu. Gazomierze poddawane są działaniu niskich temperatur występujących zimą, wysokich temperatur latem oraz czynni- ków atmosferycznych, takich jak wilgotność, w zależności od miejsca zainstalowania [13]. W niskich temperaturach zwiększa się kruchość zastosowanych metali i elastomerów, zmieniają się fizyczne parametry membran i uszczelnień. Wysoka temperatura nie czyni wprawdzie większych szkód, może jednak przyspieszać starzenie się części wykonanych z elastomerów [17].

Zgodnie z normą PN-EN [18] badanie trwałości gazomierzy polega na sprawdzeniu stabilności charakterystyki metrologicznej podczas ich 5000 godzin pracy ciągłej przy użyciu gazu dystrybucyjnego, przy maksymalnym strumieniu objętości $Q_{\max }$. Błędy wskazań wyznacza się po okresach pracy ciągłej gazomierzy: 250, 2000, 3500 i 5000 godzin. Błędy wskazań gazomierzy podczas próby trwałości powinny mieścić się w zakresie dopuszczalnych błędów granicznych podanych w normie PN-EN [18].

\section{Odporność na parę wodną, mieszaninę par toluen/izooktan oraz starzenie}

Na wartość błędu wskazań gazomierza, poza omówionymi wcześniej czynnikami takimi jak: temperatura otoczenia i gazu czy trwałość, mają również wpływ czynniki chemiczne, które mogą znaleźć się w gazie, oraz fizyczne, które mogą oddziaływać na części wewnętrzne gazomierza, a tym samym na jego właściwości metrologiczne. Do czynników chemicznych zalicza się parę wodną oraz pary toluenu/izo- oktanu. Czynnikiem fizycznym jest ekstremalnie wysoka temperatura, w której bada się tzw. starzenie.

Badania wymagane przez normę [18], tj. badanie odporności na parę wodną, mieszaninę par toluen/izooktan oraz badanie starzenia, mają za zadanie sprawdzić odporność gazomierza na działanie niekorzystnych warunków chemicznych i fizycznych.

\section{Straty spowodowane nielegalnym poborem gazu}

Przez pojęcie nielegalnego poboru paliwa gazowego rozumie się [14]:

- pobieranie gazu bez zawartej umowy sprzedaży,

- pobieranie gazu z całkowitym lub częściowym pominięciem układu pomiarowego,

- ingerencję w układ pomiarowy powodującą zafałszowanie pomiarów dokonywanych przez ten układ.

W celu oszacowania skali nielegalnego poboru przedsiębiorstwa gazownicze wykonują bezpośrednie kontrole i analizy dotyczące tego problemu. Autorom niniejszego artykułu nie udało się uzyskać danych na ten temat, dzięki którym możliwe byłoby chociaż częściowe oszacowanie skali problemu. W materiałach konferencyjnych [12] przytacza się wyniki jednej z takich kontroli, podając wykryte źródła ingerencji (w kolejności od najczęściej wykrywanych):

- ingerencja w liczydło gazomierza (jednorazowa trwale uszkadzająca części mechanizmu pomiarowego lub wielokrotna, np. poprzez wsuwanie obcego przedmiotu pod osłonę liczydła i zatrzymywanie jego biegu),

- ingerencja w mechanizmy wewnętrzne gazomierza (w tym głównie celowe uszkodzenia kanału wylotowego),

- ominięcie urządzenia pomiarowego (obejście),

- spięcie instalacji w miejscu montażu gazomierza,

- pobór gazu bezpośrednio z przyłącza przy braku umowy sprzedaży,

- inne.

Jak widać, najczęstszy sposób kradzieży gazu stanowi ingerencja w liczydło lub mechanizm wewnętrzny gazomierza, stąd bardzo istotne jest zwrócenie uwagi na tę kwestię w momencie zakupu urządzenia i wybór takiego gazomierza, którego konstrukcja możliwie jak najbardziej utrudnia tego typu ingerencje.

\section{Baza danych}

Przy tworzeniu algorytmu wykorzystano bazę danych zawartą w pracy [16]. W pracy tej, której autorami są pracow- nicy INiG - PIB, podano faktyczne zużycia gazu z okresu kilku lat, z uwzględnieniem wielkości poboru, daty, godziny, 
jak również temperatury gazu i temperatury otoczenia gazomierza. Dane pochodzą z rejestratorów zamontowanych na gazomierzach u kilkudziesięciu odbiorców indywidualnych zlokalizowanych w różnych częściach Polski. Baza danych udostępnia dane minutowe, umożliwiające oszacowanie strumieni chwilowych. Dogłębna analiza zarejestrowanych pomiarów dała szereg niezbędnych danych wejściowych do tworzonego algorytmu optymalizacji, będącego jednym z najistotniejszych elementów przeprowadzonych badań.

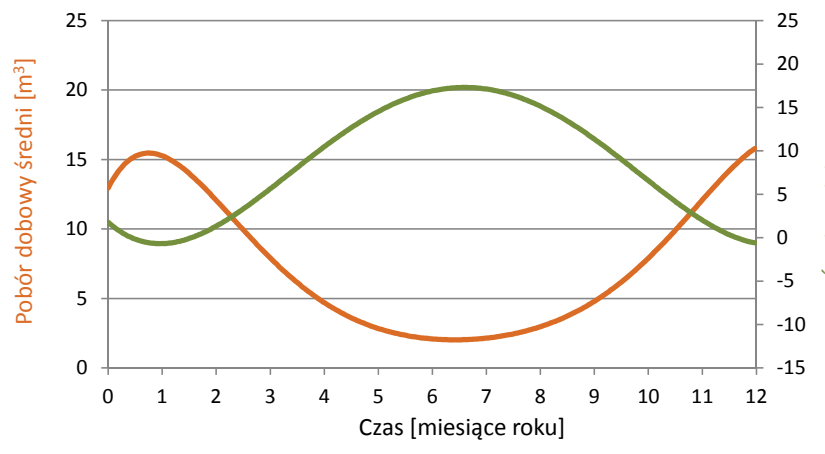

Rys. 1. Profil roczny poboru średniego dobowego przez jednego odbiorcę w taryfie W3 [16]

Jedną z informacji uzyskanych z tej bazy były profile roczne poboru gazu. Dla wszystkich rozważanych grup taryfowych kształt krzywych poboru jest zbliżony. Zasadnicza różnica - co zrozumiałe - widoczna jest dla wielkości poboru dobowego. Dla przykładu na rysunku 1 przedstawiony został profil roczny średniego poboru gazu przez jednego odbiorcę przyporządkowany do taryfy W3. Profil ten nałożony został na krzywą średnich dobowych temperatur otoczenia. W taryfie W1, w której gaz wykorzystuje się głównie do przygotowywania posiłków, wielkość jego poboru w okresie zimowym jest tylko dwukrotnie większa niż w letnim. Wraz ze wzrostem taryfy stosunek ten wzrasta. $\mathrm{W}$ taryfach $\mathrm{W} 2 \div \mathrm{W} 4$ dominującym zastosowaniem gazu jest odpowiednio podgrzewanie wody oraz ogrzewanie pomieszczeń. W taryfie W4 pobór zimowy jest aż sześciokrotnie większy od poboru letniego. Na rysunku 2 przedstawiono roczny średni rozkład chwilowych temperatur otoczenia występujących na terenie Polski (średnia z lat 2005-2008). Należy też zauważyć, że wielkość poboru zależy w dużym stopniu od położenia geograficznego. Znacznie większe zużycia gazu występują na terenach wyżynnych i górskich, gdzie sezon grzewczy trwa dłużej, a zimy są ostrzejsze (np. Zakopane, Krynica), a mniejsze w innych rejonach kraju (np. Kraków, Łódź, Poznań).

Istotne dane na temat zróżnicowania poboru gazu w Polsce znaleziono również w opracowaniu GUS [7]. Typowe zapotrzebowanie na ogrzewanie domu jednorodzinnego jest około 20 razy wyższe niż typowe zapotrzebowanie gospodarstw domowych na gotowanie posiłków. Jednocześnie zbadano, że wśród konsumentów gazu praktycznie wszyscy używają go do gotowania posiłków, połowa do ogrzewania wody, a tylko $18 \%$ do ogrzewania mieszkań. Z tego powodu rozkład zmiennej określającej wielkość zużycia gazu jest rozkładem zbliżonym do wykładniczego, tzn. istnieje bardzo dużo odbiorców charakteryzujących się małym poborem gazu i znacznie mniej odbiorców o większym poborze.

Tablica 3 przedstawia udział gospodarstw domowych w poszczególnych przedziałach rocznego zużycia gazu ziemnego wysokometanowego oraz gazu ziemnego zaazotowanego. Ponad 90\% zużycia gazu w Polsce stanowi zużycie

Tablica 3. Gospodarstwa domowe w poszczególnych przedziałach rocznego zużycia gazu ziemnego - dane za rok 2012 [7]

\begin{tabular}{|l|c|c|c|c|c|c|c|c|}
\hline \multicolumn{7}{|c|}{ Gaz ziemny wysokometanowy } \\
\hline Przedziały zużycia $\left[\mathrm{m}^{3}\right]$ & do 100 & $101-200$ & $201-300$ & $301-600$ & $601-1200$ & ponad 1200 & brak danych \\
\hline Udział gospodarstw domowych [\%] & 6,67 & 11,86 & 8,68 & 11,38 & 6,48 & 4,15 & 50,77 \\
\hline \multicolumn{7}{|c|}{ Gaz ziemny zaazotowany } \\
\hline Przedziały zużycia $\left[\mathrm{m}^{3}\right]$ & do 100 & $101-200$ & $201-300$ & $301-600$ & $601-1200$ & ponad 1200 & brak danych \\
\hline Udział gospodarstw domowych [\%] & 6,58 & 14,36 & 2,94 & 6,37 & 7,59 & 5,67 & 56,49 \\
\hline
\end{tabular}


gazu wysokometanowego. W sumie gospodarstwa należące do pierwszych czterech przedziałów to ponad $3 / 4$ odbiorców gazu, a razem z przedziałem piątym stanowią ponad $90 \%$ odbiorców (dla których uzyskano dane o zużyciu). Praktycznie rzecz biorąc, można utożsamić konsumentów w dwóch lub trzech pierwszych przedziałach, jeżeli gaz zużywany jest wyłącznie do gotowania posiłków, w przedziale czwartym i piątym, jeżeli stosuje się go do gotowania i ogrzewania wody (ewentualnie w piątym również do ogrzewania małych mieszkań), a odbiorców w przedziale szóstym, jeżeli zużywają gaz do ogrzewania domów.

Po analizie i wyznaczeniu histogramów okazało się, że dominującym strumieniem we wszystkich rozpatrywanych taryfach był strumień w zakresie od 0 do $0,3 \mathrm{~m}^{3} / \mathrm{h}$. Występuje on głównie w przypadku przygotowywania posiłków. $\mathrm{W}$ taryfie $\mathrm{W} 1 \mathrm{w}$ tym zakresie strumieni gazomierz odmierza w przybliżeniu 55\% całkowitej objętości pobranego gazu. Udziały wyższych strumieni związane są głównie z częstością korzystania z podgrzewacza wody. Udział żadnego z nich nie przekracza $12 \%$. W wyższych taryfach, w których wystę- puje użytkowanie gazu na potrzeby grzewcze, udział wyższych strumieni wzrasta. Maksymalny zarejestrowany strumień wyniósł $7,2 \mathrm{~m}^{3} / \mathrm{h}$. Niezmiennie jednak dominującym pozostaje strumień do $0,3 \mathrm{~m}^{3} / \mathrm{h}$. Dla przykładu na rysunku 3 przedstawiono histogram rozkładu częstości występowania poszczególnych strumieni u odbiorcy w taryfie W3.

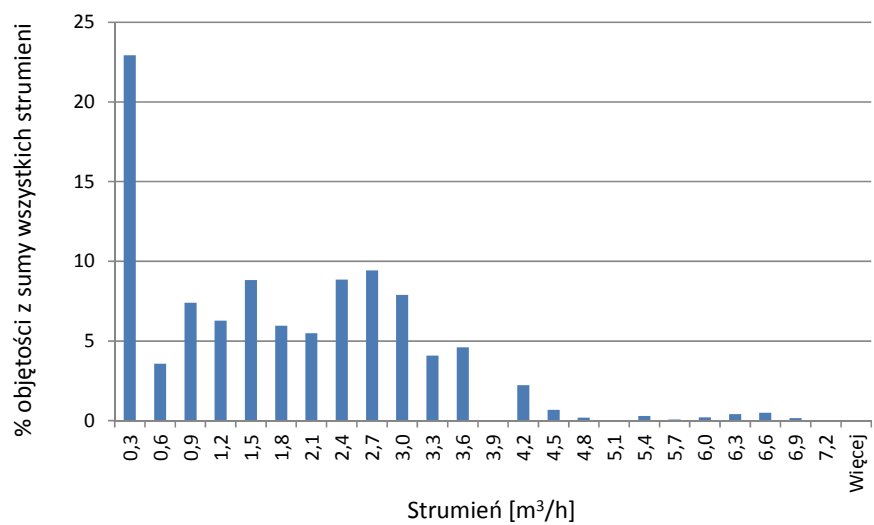

Rys. 3. Rozkład częstości występowania poszczególnych strumieni w taryfie W3 [16]

\section{Algorytm optymalizujący dobór gazomierza}

Analizując wartości określające poszczególne charakterystyki gazomierza, trudno stwierdzić, jaki w rzeczywistości będą one miały wpływ na straty lub zyski dla właściciela gazomierza (operatora systemu gazowniczego). Przedstawiony algorytm ma ułatwić to zadanie. Działanie algorytmu polega na określeniu wielkości wpływu poszczególnych wartości błędów z charakterystyki gazomierza na skalę niedomierzonych ilości gazu, a co za tym idzie - na wielkość zysków lub strat finansowych dla sprzedawcy gazu. Aby to było możliwe, należy znać rzeczywiste wielkości strumieni gazu przepływających przez gazomierz oraz warunki temperaturowe, w jakich urządzenie będzie pracować. Oczywiście nie można ich precyzyjnie przewidzieć, ale można je określić w przybliżeniu, obserwując i rejestrując dane pomiarowe z gazomierzy już pracujących w badanym terenie. Uzyskana w ten sposób baza danych posłużyła jako podstawa działania niniejszego algorytmu optymalizującego dobór gazomierzy.

Algorytm podzielony został na sześć części składowych. Każda odpowiada za oszacowanie wpływu jednego parametru. Pierwszym z rozpatrywanych parametrów jest błąd podstawowy/pierwotny. W tym przypadku obliczenia są bardzo proste. Znając średnie roczne zużycie gazu w danej taryfie oraz rozkład częstości występowania poszczególnych strumieni w danej taryfie, można oszacować ilość pobranego w ciągu roku gazu. Następnie rejestrowane ilości gazu należy przemnożyć przez błąd odpowiadający danemu strumieniowi. Wartości błędów dla strumieni pośrednich w stosunku do wartości zdefiniowanych przez normę [18] uzyskuje się poprzez interpolację liniową. Zsumowanie wartości otrzymanych dla wszystkich strumieni da informację o wielkości zysków lub strat mających źródło w błędach podstawowych gazomierza. Dokładnie takich samych obliczeń dokonuje się w przypadku parametrów: odporność na mieszaninę par toluen/izooktan, odporność na parę wodną oraz starzenie.

Analogiczne obliczenia przeprowadza się również w przypadku błędów temperaturowych, z tym że dodatkowo dla każdego strumienia należy uwzględnić częstość występowania poszczególnych wartości temperatur. $\mathrm{W}$ przypadku badań gazomierza w deklarowanym zakresie temperatury otoczenia i gazu norma [18] definiuje tylko trzy temperatury: minimalną, maksymalną oraz pośrednią $(20 \pm 5)^{\circ} \mathrm{C}$. W celu uzyskania wartości pośrednich dla wymienionych powyżej, podobnie jak dla strumieni, zastosowano interpolację liniową. W pozycji [4] można znaleźć doświadczalnie wyznaczony rozkład błędów w całym zakresie temperaturowym.

Nieco bardziej skomplikowana sytuacja występuje w przypadku badania trwałości. Tutaj należy średni dziesięcioletni pobór gazu rozbić na zakresy poboru gazu odpowiadające pracy danego gazomierza przy strumieniu $Q_{\max }$ przez kolejno 250, 2000, 3500 i 5000 godzin. Dla każdego zakresu godzinowego należy wprowadzić błędy z charakterystyki gazomierza. Dalsze obliczenia wykonuje się podobnie jak przy błędach podstawowych. 
Ostatnim z parametrów są straty wynikające z nielegalnego poboru gazu. Jak już wspomniano wcześniej, autorom nie udało się odnaleźć danych liczbowych dotyczących tego zjawiska. W związku z tym algorytm nie zawie- ra obliczeń z tym związanych, jednakże pozostawia możliwość uwzględnienia tych danych w sytuacji, gdy kupujący potrafi sam oszacować wielkość strat gazu związanych $\mathrm{z}$ tym problemem.

\section{Aplikacja oparta na opracowanym algorytmie}

Aplikacja komputerowa wykorzystująca omówiony algorytm została stworzona w środowisku MS Excel. Obsługa programu jest bardzo intuicyjna. W sekcji pierwszej należy wprowadzić dane początkowe, tj.: taryfę, w której zakupione gazomierze będą pracować, wielkość gazomierzy, okres eksploatacji, liczbę sztuk przewidzianych do zakupu oraz szacunkowy średni koszt jednego metra sześciennego gazu w całym okresie eksploatacji gazomierza. Na- leży podać również cenę wszystkich porównywanych rodzajów gazomierzy.

Według [9] zdecydowaną większość gazomierzy miechowych $(99,2 \%)$ stanowią gazomierze o wielkości od G1 do G6, w związku z tym aplikacja dopuszcza wybór gazomierzy od G1,6 do maksymalnie G10. Równocześnie można porównać do trzech gazomierzy tej samej wielkości. Na podstawie wprowadzonej grupy taryfowej aplikacja będzie mogła określić m.in.

\section{CHARAKTERYSTYKA GAZOMIERZY}

\begin{tabular}{|c|c|c|c|c|c|c|c|c|}
\hline \multicolumn{9}{|c|}{ Bląd podstawowy } \\
\hline & & $Q_{\min }$ & $3 Q_{\min }$ & $0,1 Q_{\max }$ & $0,2 Q_{\max }$ & $0,4 Q_{\max }$ & $0,7 Q_{\max }$ & $Q_{\max }$ \\
\hline \multicolumn{2}{|c|}{$Q\left[\mathrm{~m}^{3} / \mathrm{h}\right]$} & 0,016 & 0,048 & 0,25 & 0,5 & 1 & 1,75 & 2,5 \\
\hline \multirow{3}{*}{$\mathrm{E}[\%]$} & Gazomierz 1 & $-0,35$ & $-0,54$ & 0,14 & 0,25 & 0,16 & 0,41 & 0,46 \\
\hline & Gazomierz 2 & $-0,11$ & 0,47 & 0,93 & 1,10 & 0,86 & 0,72 & 0,92 \\
\hline & Gazomierz 3 & 0,44 & 0,87 & 1,01 & 0,82 & 0,90 & 0,67 & 0,71 \\
\hline
\end{tabular}

Błąd temperaturowy

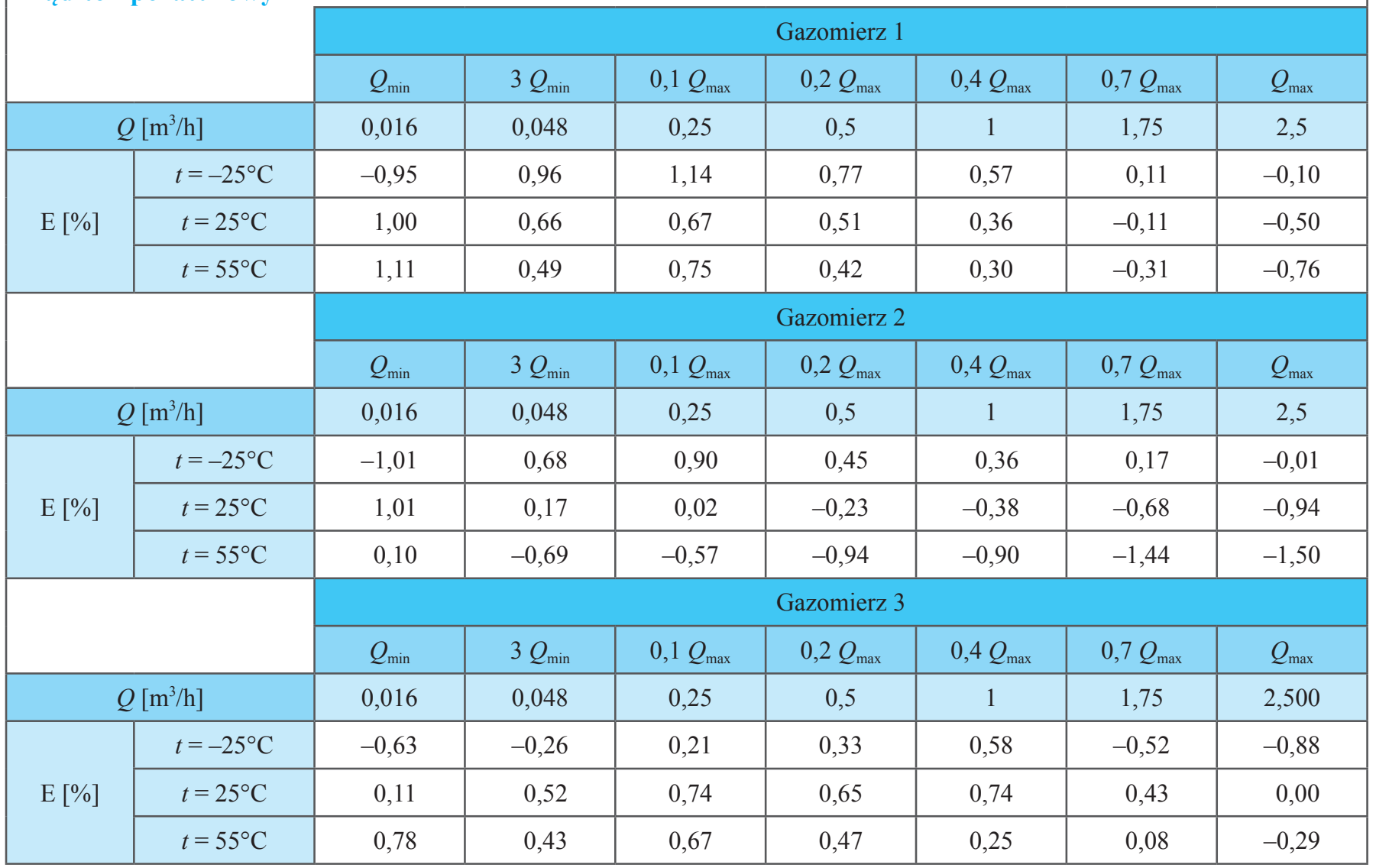

Rys. 4. Formularz wprowadzania wartości błędów podstawowych i temperaturowych 
szacunkowe zużycie gazu w okresie eksploatacji, wielkości strumieni, przy których gazomierze będą pracować, temperatury otoczenia $i$ inne niezbędne dane potrzebne do porównania.

Przy wprowadzaniu danych z charakterystyki (rysunki 4־6) gazomierzy należy wypełnić wszystkie komórki do tego przeznaczone. W przypadku gdy kupujący dysponuje szacunkowymi danymi na temat skali nieuprawnionych ingerencji $\mathrm{w}$ dany typ gazomierza $\mathrm{i}$ jest $\mathrm{w}$ stanie oszacować wielkość strat gazu z tym związanych, może wprowadzić te dane. W przeciwnym wypadku w parametrze ,nielegalny pobór gazu" należy pozostawić zera.

W trzeciej sekcji - ,Wyniki porównania gazomierzy” nie należy wprowadzać żadnych danych. Prezentowane są tu wyniki obliczeń. Dla każdego gazomierza wprowadzono następujące dane:

- sumaryczny koszt zakupu zadeklarowanej liczby gazomierzy,
- niedomierzone ilości gazu dla każdego z parametrów dla jednego gazomierza $\left[\mathrm{m}^{3} / 10\right.$ lat $]$,

- sumaryczny błąd dla jednego gazomierza [m³/10 lat],

- sumaryczny błąd dla zadeklarowanej liczby gazomierzy $\left[\mathrm{m}^{3} / 10\right.$ lat $]$,

- sumaryczny błąd dla jednego gazomierza przeliczony na PLN,

- sumaryczny błąd dla zadeklarowanej liczby gazomierzy przeliczony na PLN.

Końcowym wynikiem działania aplikacji jest wyświetlenie efektu ekonomicznego uwzględniającego koszt zakupu zadeklarowanej liczby gazomierzy oraz zysków lub strat związanych z niepoprawnie rozliczonymi ilościami gazu. Aplikacja za pomocą kolorowej skali wskazuje najkorzystniejszy wybór (kolor zielony). Podobnie najmniej korzystna opcja podświetlana jest na czerwono.

\begin{tabular}{|c|c|c|c|c|c|c|c|}
\hline \multicolumn{8}{|l|}{ Trwałość } \\
\hline & \multicolumn{7}{|c|}{ Gazomierz 1} \\
\hline & $Q_{\min }$ & $3 Q_{\min }$ & $0,1 Q_{\max }$ & $0,2 Q_{\max }$ & $0,4 Q_{\max }$ & $0,7 Q_{\max }$ & $Q_{\max }$ \\
\hline$Q\left[\mathrm{~m}^{3} / \mathrm{h}\right]$ & 0,016 & 0,048 & 0,25 & 0,5 & 1 & 1,75 & 2,5 \\
\hline E1 [\%] (po 0 h) & 0,00 & 0,30 & 0,30 & 0,19 & 0,19 & $-0,12$ & $-0,19$ \\
\hline E2 [\%] (po 250 h) & 0,15 & 0,26 & 0,08 & 0,06 & $-0,04$ & $-0,36$ & $-0,40$ \\
\hline E3 [\%] (po 2000 h) & 0,19 & 0,18 & $-0,19$ & $-0,29$ & $-0,37$ & $-0,72$ & $-0,81$ \\
\hline E4 [\%] (po 3500 h) & 1,12 & 0,46 & 0,23 & 0,52 & 0,44 & $-0,10$ & $-0,35$ \\
\hline \multirow[t]{3}{*}{ E5 [\%] (po 5000 h) } & $-0,27$ & 0,15 & 0,02 & 0,11 & $-0,11$ & $-0,52$ & $-0,63$ \\
\hline & \multicolumn{7}{|c|}{ Gazomierz 2} \\
\hline & $Q_{\min }$ & $3 Q_{\min }$ & $0,1 Q_{\max }$ & $0,2 Q_{\max }$ & $0,4 Q_{\max }$ & $0,7 Q_{\max }$ & $Q_{\max }$ \\
\hline$Q\left[\mathrm{~m}^{3} / \mathrm{h}\right]$ & 0,016 & 0,048 & 0,25 & 0,5 & 1 & 1,75 & 2,5 \\
\hline E1 [\%] (po 0 h) & $-0,20$ & 0,16 & $-0,06$ & $-0,14$ & $-0,15$ & $-0,37$ & $-0,33$ \\
\hline E2 [\%] (po 250 h) & 0,18 & 0,02 & $-0,14$ & $-0,25$ & $-0,15$ & $-0,46$ & $-0,50$ \\
\hline E3 [\%] (po 2000 h) & 0,10 & $-0,01$ & $-0,54$ & $-0,61$ & $-0,65$ & $-0,91$ & $-0,62$ \\
\hline E4 [\%] (po 3500 h) & 1,07 & 0,32 & 0,17 & 0,30 & 0,25 & $-0,29$ & $-0,47$ \\
\hline \multirow[t]{3}{*}{ E5 [\%] (po 5000 h) } & $-0,54$ & $-0,06$ & $-0,01$ & $-0,13$ & $-0,37$ & $-0,56$ & $-0,71$ \\
\hline & \multicolumn{7}{|c|}{ Gazomierz 3} \\
\hline & $Q_{\min }$ & $3 Q_{\min }$ & $0,1 Q_{\max }$ & $0,2 Q_{\max }$ & $0,4 Q_{\max }$ & $0,7 Q_{\max }$ & $Q_{\max }$ \\
\hline$Q\left[\mathrm{~m}^{3} / \mathrm{h}\right]$ & 0,016 & 0,048 & 0,25 & 0,5 & 1 & 1,75 & 2,5 \\
\hline E1 [\%] (po 0 h) & $-0,09$ & 0,21 & 0,08 & 0,05 & 0,04 & $-0,23$ & $-0,26$ \\
\hline E2 [\%] (po 250 h) & 0,28 & 0,06 & $-0,25$ & $-0,22$ & $-0,15$ & $-0,51$ & $-0,50$ \\
\hline E3 [\%] (po 2000 h) & 0,01 & $-0,18$ & $-0,55$ & $-0,56$ & $-0,54$ & $-0,87$ & $-0,77$ \\
\hline E4 [\%] (po 3500 h) & 0,98 & 0,19 & 0,13 & 0,12 & 0,19 & $-0,24$ & $-0,38$ \\
\hline E5 [\%] (po 5000 h) & $-0,40$ & $-0,21$ & $-0,33$ & $-0,13$ & $-0,42$ & $-0,64$ & $-0,81$ \\
\hline
\end{tabular}

Rys. 5. Formularz wprowadzania wartości błędów z badania trwałości 


\begin{tabular}{|c|c|c|c|c|c|c|c|c|c|c|}
\hline & \multicolumn{3}{|c|}{ Gazomierz 1} & \multicolumn{3}{|c|}{ Gazomierz 2} & \multicolumn{3}{|c|}{ Gazomierz 3} \\
\hline & & $0,1 Q_{\max }$ & $0,4 Q_{\max }$ & $Q_{\max }$ & $0,1 Q_{\max }$ & $0,4 Q_{\max }$ & $Q_{\max }$ & $0,1 Q_{\text {max }}$ & $0,4 Q_{\max }$ & $Q_{\max }$ \\
\hline & $Q\left[\mathrm{~m}^{3} / \mathrm{h}\right]$ & 0,25 & 1 & 2,5 & 0,25 & 1 & 2,5 & 0,25 & 1 & 2,5 \\
\hline \multirow{2}{*}{$\mathrm{E}[\%]$} & Przed badaniem & $-0,53$ & $-0,52$ & $-0,64$ & 0,29 & 0,12 & $-0,42$ & 0,52 & 0,20 & $-0,52$ \\
\hline & Po badaniu & $-0,42$ & $-0,45$ & $-0,81$ & 0,50 & 0,12 & $-0,44$ & 0,65 & 0,27 & $-0,56$ \\
\hline
\end{tabular}

\begin{tabular}{|c|c|c|c|c|c|c|c|c|c|c|}
\hline \multicolumn{11}{|c|}{ Odporność na parę wodną } \\
\hline & & \multicolumn{3}{|c|}{ Gazomierz 1} & \multicolumn{3}{|c|}{ Gazomierz 2} & \multicolumn{3}{|c|}{ Gazomierz 3} \\
\hline & & $0,1 Q_{\max }$ & $0,4 Q_{\max }$ & $Q_{\max }$ & $0,1 Q_{\max }$ & $0,4 Q_{\max }$ & $Q_{\max }$ & $0,1 Q_{\max }$ & $0,4 Q_{\max }$ & $Q_{\max }$ \\
\hline & $Q\left[\mathrm{~m}^{3} / \mathrm{h}\right]$ & 0,25 & 1 & 2,5 & 0,25 & 1 & 2,5 & 0,25 & 1 & 2,5 \\
\hline \multirow{2}{*}{$\mathrm{E}[\%]$} & Przed badaniem & $-0,39$ & $-0,40$ & $-0,38$ & 0,17 & $-0,43$ & $-1,11$ & 0,43 & 0,04 & $-0,72$ \\
\hline & Po badaniu & $-0,49$ & $-0,54$ & $-1,19$ & 0,55 & 0,15 & $-0,46$ & 0,62 & 0,14 & $-0,42$ \\
\hline
\end{tabular}

Badanie starzenia

\begin{tabular}{|c|l|c|c|c|c|c|c|c|c|c|}
\cline { 3 - 11 } & \multicolumn{3}{|c|}{ Gazomierz } & \multicolumn{3}{c|}{ Gazomierz 2 } & \multicolumn{4}{c|}{ Gazomierz 3} \\
\cline { 3 - 11 } & $0,1 Q_{\max }$ & $0,4 Q_{\max }$ & $Q_{\max }$ & $0,1 Q_{\max }$ & $0,4 Q_{\max }$ & $Q_{\max }$ & $0,1 Q_{\max }$ & $0,4 Q_{\max }$ & $Q_{\max }$ \\
\hline \multicolumn{2}{|c|}{$Q\left[\mathrm{~m}^{3} / \mathrm{h}\right]$} & 0,25 & 1 & 2,5 & 0,25 & 1 & 2,5 & 0,25 & 1 & 2,5 \\
\hline E $[\%]$ & Po badaniu & 0,12 & 0,23 & $-0,60$ & 0,61 & 0,17 & $-0,24$ & 0,23 & $-0,52$ & $-1,75$ \\
\hline
\end{tabular}

Straty wynikające $\mathrm{z}$ nielegalnego poboru gazu

\begin{tabular}{c|c|c|c}
\cline { 2 - 4 } & Gazomierz 1 & Gazomierz 2 & Gazomierz 3 \\
$\begin{array}{c}\text { Szacunkowe } \\
\text { straty }\left[\mathrm{m}^{3} / \mathrm{rok}\right]\end{array}$ & 0 & 0 & 0 \\
\hline
\end{tabular}

Rys. 6. Formularz wprowadzania pozostałych wartości błędów

\section{Przykładowe porównanie gazomierzy - analiza wyników porównania}

W ramach sprawdzenia wykonano przykładowe porównanie kilku typów gazomierzy. Przy doborze danych wejściowych dotyczących liczby i wielkości gazomierzy sugerowano się danymi z rzeczywistych przetargów odnalezionych w sieci WWW. Charakterystyki gazomierzy zasymulowano, aczkolwiek zbliżone są one do wartości, jakie typowo występują dla rozważanych parametrów. Pierwszym przykładem (rysunek 7) był zakup 54280 sztuk gazomierzy wielkości G1,6. Przewidywane zastosowanie większości z nich to praca $\mathrm{w}$ zakresie taryfy W1. Założone ceny porównywanych gazomierzy wynoszą kolejno: 89 zł, 105 zł i 110 zł za sztukę. Po przeanalizowaniu charakterystyk urządzeń aplikacja jako najkorzystniejszy wybór wskazuje gazomierz oznaczony numerem 2 . Obliczenia pokazują, że w trakcie całego okresu eksploatacji pozwoli on, z uwagi na swoje dodatnie błędy, na osiągnięcie optymalnych efektów ekonomicznych, korzystnych dla właściciela gazomierza. Oszacowane superaty związane $\mathrm{z}$ nierozliczoną ilością gazu wyniosą $\mathrm{w}$ tym przypadku w przybliżeniu $2,84 \mathrm{mln}$ zł, podczas gdy w sytuacji zastosowania gazomierza $\mathrm{nr} 1$ osiągną około 156 tys. zł.
Drugi przykład (rysunek 8) dotyczy 4380 sztuk gazomierzy G6, z przewidywanym zastosowaniem do pracy w zakresie taryfy W3. Koszt zakupu gazomierzy wynosi kolejno 170 zł, 190 zł i 210 zł za sztukę. Aplikacja jako najkorzystniejszy wybór wskazuje urządzenie najtańsze. Straty związane $\mathrm{z}$ nierozliczoną ilością gazu będą $\mathrm{w}$ tym przypadku najmniejsze, tj. około 1,5 mln zł, co stanowi w przybliżeniu aż 200\% kosztów zakupu. W przypadku gazomierza najmniej ekonomicznego (gazomierz nr 3) straty wynikające z nierozliczonych ilości gazu wyniosłyby aż $2,89 \mathrm{mln}$ zł. W ostatecznym rozrachunku kupujący, wybierając gazomierz oznaczony numerem 1, w ciągu 10 lat eksploatacji zaoszczędzi około 1,56 mln zł w stosunku do gazomierza 3 .

Trzeci przykład (rysunek 9) dotyczy gazomierzy G10 przeznaczonych do pracy w zakresie taryfy W4. Deklarowana liczba sztuk do zakupu to 2370. Koszt zakupu gazomierzy wynosi kolejno 460 zł, 490 zł i 520 zł. Aplikacja jako najkorzystniejszy wybór wskazuje urządzenie w cenie 490 zł. $\mathrm{Z}$ uwagi na stosunkowo duże dodatnie początkowe błędy wskazań gazomierz przyniesie superaty, które wyniosą około 


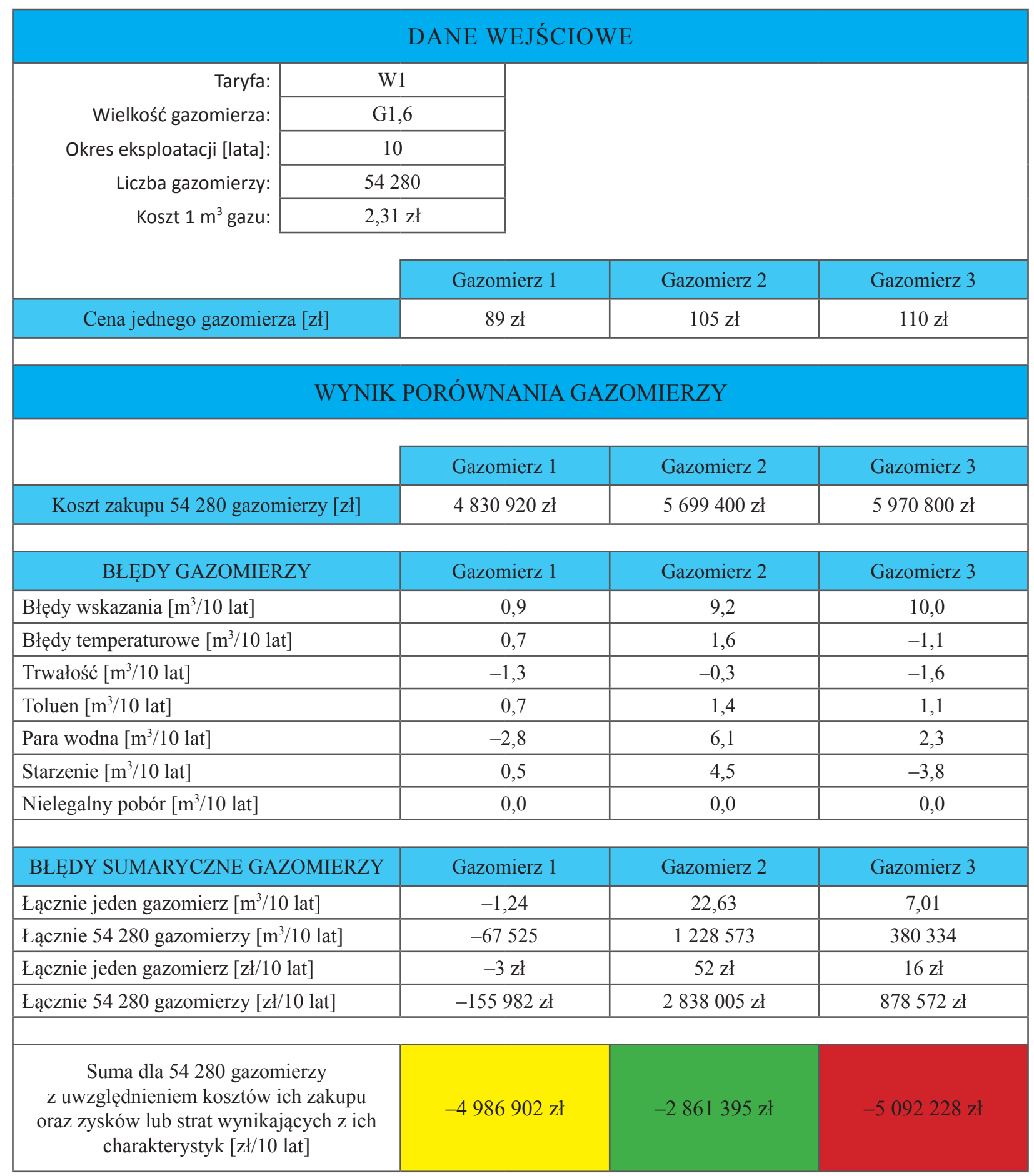

Rys. 7. Porównanie trzech gazomierzy typu G1,6

4,86 mln zł, podczas gdy w najgorszym przypadku będą to straty w wysokości około 95 tys. zł (gazomierz nr 3). Oszacowany zysk ponad czterokrotnie przekracza koszt zakupu gazomierzy. Zakup gazomierza oznaczonego numerem 2 po- zwoli na uzyskanie 2,55 mln zł oszczędności w stosunku do drugiego w kolejności oraz około 5,03 mln zł w stosunku do najgorszego. W tym porównaniu gazomierz najdroższy okazał się również najdroższym w eksploatacji.

\section{Podsumowanie}

Według przepisów koszt zakupu i wymiany gazomierzy pokrywa operator systemu gazowniczego. W przypadku konieczności zakupu większej liczby urządzeń pomia- rowych koszty te często sięgają milionów złotych. Dodatkowo mogą się one jeszcze bardziej zwiększyć, jeśli weźmie się pod uwagę straty związane z właściwościami 


\begin{tabular}{|c|c|c|c|c|}
\hline \multicolumn{5}{|c|}{ DANE WEJŚCIOWE } \\
\hline \multicolumn{5}{|l|}{ Taryfa: } \\
\hline \multirow{5}{*}{$\begin{array}{r}\text { Wielkość gazomierza: } \\
\text { Okres eksploatacji [lata]: } \\
\text { Liczba gazomierzy: } \\
\text { Koszt } 1 \mathrm{~m}^{3} \text { gazu: }\end{array}$} & \multicolumn{2}{|c|}{ G6 } & & \\
\hline & \multicolumn{2}{|c|}{10} & & \\
\hline & \multicolumn{2}{|c|}{4380} & & \\
\hline & \multicolumn{2}{|c|}{$2,31 \mathrm{zł}$} & & \\
\hline & & Gazomierz 1 & Gazomierz 2 & Gazomierz 3 \\
\hline \multicolumn{2}{|c|}{ Cena jednego gazomierza [zł] } & $170 \mathrm{zl}$ & $190 \mathrm{zł}$ & $210 \mathrm{zl}$ \\
\hline \multicolumn{5}{|c|}{ WYNIK PORÓWNANIA GAZOMIERZY } \\
\hline & & Gazomierz 1 & Gazomierz 2 & Gazomierz 3 \\
\hline \multicolumn{2}{|c|}{ Koszt zakupu 4380 gazomierzy [zł] } & $744600 \mathrm{zl}$ & $832200 \mathrm{zł}$ & $919800 \mathrm{zł}$ \\
\hline \multicolumn{2}{|c|}{ BŁĘDY GAZOMIERZY } & Gazomierz 1 & Gazomierz 2 & Gazomierz 3 \\
\hline \multicolumn{2}{|c|}{ Błędy wskazania $\left[\mathrm{m}^{3} / 10\right.$ lat $]$} & 21,1 & $-10,4$ & $-112,7$ \\
\hline \multicolumn{2}{|l|}{ Błędy temperaturowe $\left[\mathrm{m}^{3} / 10\right.$ lat $]$} & $-41,0$ & $-68,0$ & 76,0 \\
\hline \multicolumn{2}{|l|}{ Trwałość $\left[\mathrm{m}^{3} / 10\right.$ lat $]$} & $-36,3$ & $-86,7$ & $-90,6$ \\
\hline \multicolumn{2}{|l|}{ Toluen $\left[\mathrm{m}^{3} / 10\right.$ lat $]$} & $-117,8$ & $-118,2$ & $-165,4$ \\
\hline \multicolumn{2}{|l|}{ Para wodna [m³/10 lat] } & $-88,3$ & $-82,3$ & $-81,3$ \\
\hline \multicolumn{2}{|l|}{ Starzenie $\left[\mathrm{m}^{3} / 10\right.$ lat $]$} & 113,6 & 83,4 & 88,7 \\
\hline \multicolumn{2}{|l|}{ Nielegalny pobór [m³/10 lat] } & 0,0 & 0,0 & 0,0 \\
\hline \multicolumn{2}{|c|}{ BŁĘDY SUMARYCZNE GAZOMIERZY } & Gazomierz 1 & Gazomierz 2 & Gazomierz 3 \\
\hline \multicolumn{2}{|c|}{ Łącznie jeden gazomierz $\left[\mathrm{m}^{3} / 10\right.$ lat $]$} & $-148,69$ & $-282,14$ & $-285,36$ \\
\hline \multicolumn{2}{|c|}{ Łącznie 4380 gazomierzy [m³/10 lat] } & $-651,264$ & -1235757 & -1249877 \\
\hline \multicolumn{2}{|c|}{ Łącznie jeden gazomierz [zł/10 lat] } & $-343 \mathrm{zl}$ & -652 zł & $-659 \mathrm{zl}$ \\
\hline \multicolumn{2}{|c|}{ Łącznie 4380 gazomierzy [zł/10 lat] } & $-1504419 \mathrm{zł}$ & $-2854598 \mathrm{zł}$ & $-2887215 \mathrm{zł}$ \\
\hline \multicolumn{2}{|c|}{$\begin{array}{c}\text { Suma dla } 4380 \text { gazomierzy } \\
\text { z uwzględnieniem kosztów ich zakupu } \\
\text { oraz zysków lub strat wynikających z ich } \\
\text { charakterystyk [zł/10 lat] }\end{array}$} & $-2249019 \mathrm{zl}$ & $-3686798 \mathrm{zl}$ & $-3807015 \mathrm{zl}$ \\
\hline
\end{tabular}

Rys. 8. Porównanie trzech gazomierzy typu G6

metrologicznymi gazomierzy. Generowane nierozliczone ilości gazu, jak wykazały przeprowadzone w ramach niniejszej pracy analizy, mogą osiągnąć znaczny poziom, często wielokrotnie przewyższając sam koszt zakupu gazomierzy. $\mathrm{Z}$ tego powodu bardzo ważne z punktu widzenia kupującego jest uwzględnienie nie tylko ceny licznika gazu i jego funkcjonalności, ale też jego parametrów metrologicznych. Porównanie charakterystyk metrologicznych różnych gazomierzy nie jest jednak łatwe. Wymaga posiadania sporej wiedzy i doświadczenia zarówno na temat samego gazomierza, jego działania i właściwości, jak i znajomości specyfiki warunków, w jakich to urządzenie będzie pracować, i czynników środowiskowych, jakim może zostać poddane w całym okresie eksploatacji. Z pomocą kupującemu może przyjść aplikacja opisana w niniejszym artykule. Dzięki temu, że opiera się ona na danych pomiarowych zawierających informacje o faktycznym zużyciu gazu, zmienności poboru całkowitego, a także zmianach temperatury gazu i otoczenia, możliwe jest oszacowanie wpływu poszczególnych parametrów metrologicznych na ilość nierozliczonego gazu. Aplikacja 


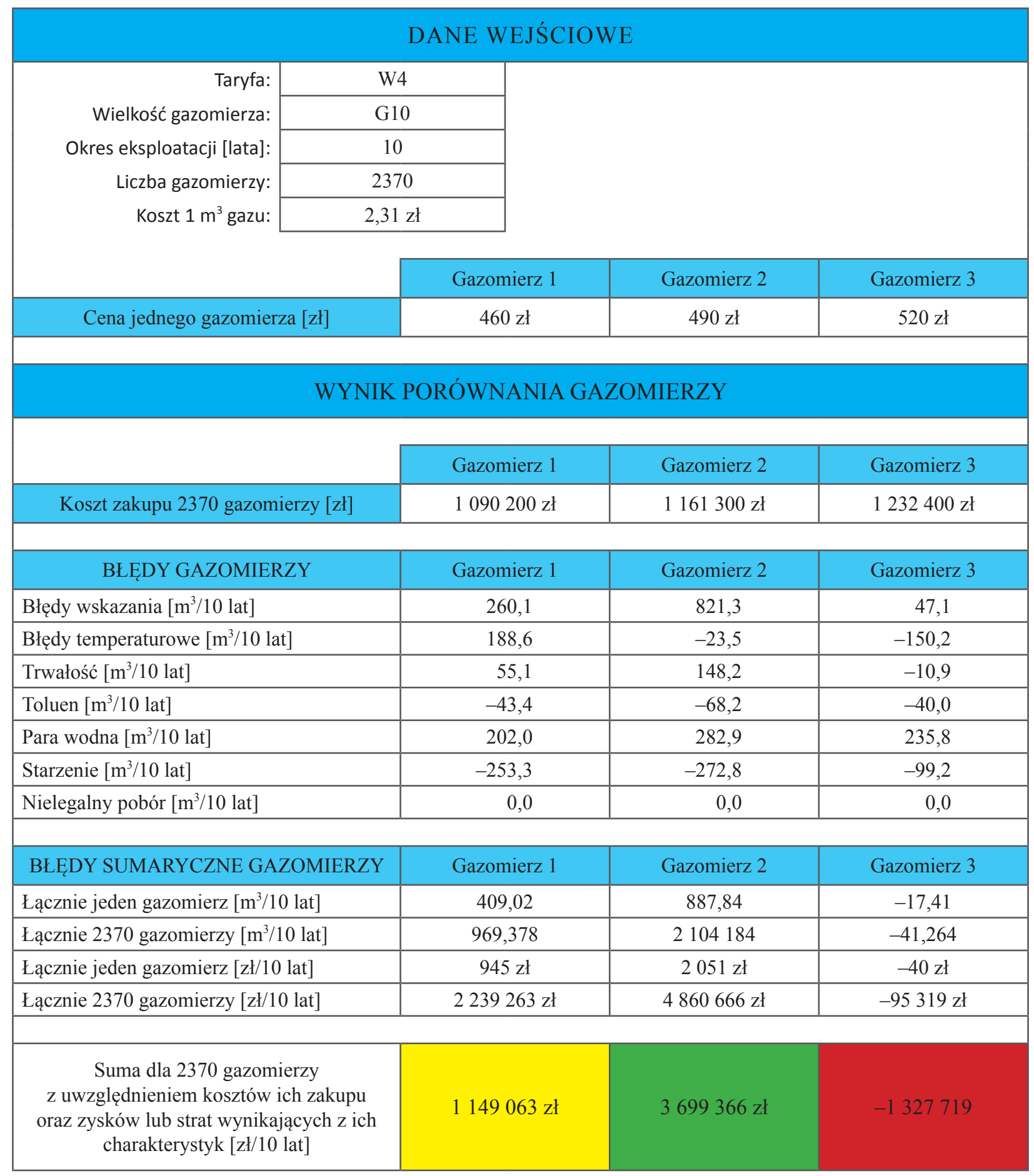

Rys. 9. Porównanie trzech gazomierzy typu G10

pozwala na dokonanie optymalnego z punktu widzenia efektywności ekonomicznej wyboru gazomierza.

Należy zaznaczyć, że w związku z tym, iż zaprezentowana $w$ tym artykule aplikacja opiera się na danych zareje- strowanych u bardzo ograniczonej liczby odbiorców gazu, wyniki jej działania są szacunkowe i należy je traktować jedynie jako materiał pomocniczy przy ostatecznym wyborze gazomierzy.

Prosimy cytować jako: Nafta-Gaz 2017, nr 4, s. 274-286, DOI: 10.18668/NG.2017.04.08

Artykuł nadesłano do Redakcji 23.12.2016 r. Zatwierdzono do druku 7.03.2017 r.

Artykuł powstał na podstawie pracy statutowej pt. Optymalizacja metod doboru gazomierzy domowych - praca INiG - PIB na zlecenie MNiSW; nr zlecenia: 0058/GM/16, nr archiwalny: DK-4100-58/16. 


\section{Literatura}

[1] Bąkowski K.: Sieci i instalacje gazowe - poradnik projektowania, budowy i eksploatacji. WNT, Warszawa 2007.

[2] Dopke J.: Gazomierze miechowe. Dobór do odbiorcy gazu. http://www.wentylacja.com.pl (dostęp: 18.10.2016).

[3] Dopke J.: Interpretacja właściwości metrologicznych gazomierzy miechowych deklarowanych przez producentów. TOP-GAZ, Rogów 2003.

[4] Dopke J.: Właściwości metrologiczne i wymagania instalacyjne gazomierzy miechowych. http://www.rynek-gazu.cire. pl (dostęp: 18.10.2016).

[5] GUS: Gospodarka paliwowo-energetyczna w latach 2013 i 2014. Warszawa 2015; http://www.stat.gov.pl (dostęp: 18.10.2016).

[6] GUS: Mały Rocznik Statystyczny Polski 2016. Warszawa 2016; http://www.stat.gov.pl (dostęp: 18.10.2016).

[7] GUS: Zużycie energii w gospodarstwach domowych w 2012 r. Warszawa 2014.

[8] Hec M., Nold B., Włodzimirow W.: Wpływ parametrów metrologicznych na koszty eksploatacji gazomierzy miechowych. Materiały konferencyjne, FORGAZ 2016.

[9] Jasiński G.: Kierunki działań PSG Sp. z o.o. w zakresie uktadów pomiarowych z gazomierzami miechowymi. TOP-GAZ, Rogów 2015.

[10] Jaworski J.: Pomiary dla klientów indywidualnych - nierozliczone ilości gazu - analiza i optymalizacja. Materiały konferencyjne „Nierozliczone ilości gazu - wyznaczanie i metody ograniczania strat”, Gdynia 17-19.10.2007.

[11] Jaworski J.: Wpływ temperatury otoczenia na prace gazomie-

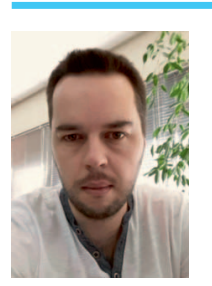

Mgr inż. Jacek MATUSIK

Starszy specjalista inżynieryjno-techniczny; Zastępca kierownika Laboratorium Wzorcującego Zakład Metrologii Przepływów

Instytut Nafty i Gazu - Państwowy Instytut Badawczy ul. Lubicz 25 A, 31-503 Kraków

E-mail: jacek.matusik@inig.pl rzy miechowych w aspekcie krajowych warunków klimatyczno-technicznych. Rozprawa doktorska, Kraków 2004.

[12] Kobierski M.: Wpływ efektów kontroli prawidtowości odbioru gazu na wielkość strat gazu na bazie doświadczeń Zakładu Gazowniczego Wroctaw, DSG Sp. z o.o. we Wroctawiu. Wrocław 2005. Materiały konferencyjne „Nierozliczone ilości gazu - wyznaczanie i metody ograniczania strat”, Gdynia 17-19.10.2007.

[13] Kułaga P., Jaworski J.: Wyniki badań trwałości gazomierzy miechowych uzyskiwane z zastosowaniem różnych metodyk - analiza porównawcza. Nafta-Gaz 2016, nr 8, s. 645-650, DOI: 10.18668/NG.2016.08.09.

[14] Polska Spółka Gazownictwa: Nielegalny pobór gazu. Strona internetowa PSG Sp. z o.o.; http://www.psgaz.pl/nielegalny-pobor-gazu (dostęp: 18.10.2016).

[15] Rybicki C., Łuczyński S.: Pomiary natężenia przepływu. Wiertnictwo, Nafta, Gaz 2007, t. 24, z. 2.

[16] Wagner-Staszewska T., Jaworski J., Gacek Z.: Wybrane problemy rozliczania zużycia gazu przez indywidualnych odbiorców. Prace Instytutu Nafty i Gazu 2007, nr 144.

[17] Wiśniowicz A.: Wpływ czynników środowiskowych i oddziatywania gazu na funkcjonowanie reduktorów średniego ciśnienia. Nafta-Gaz 2013, nr 6, s. 463-467.

\section{Akty prawne i normatywne}

[18] PN-EN 1359:2004 + PN-EN 1359:2004/A1:2006 Gazomierze. Gazomierze miechowe.

[19] PN-EN 16314:2013 Gazomierze. Dodatkowe funkcjonalności.

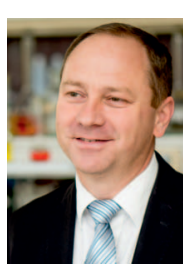

Dr inż. Jacek JAWORSKI

Adiunkt; zastępca Dyrektora ds. Gazownictwa. Instytut Nafty i Gazu - Państwowy Instytut Badawczy ul. Lubicz 25 A

31-503 Kraków

E-mail: jacek.jaworski@inig.pl 